A. friori, the more highly finished should succeed the ruder implements, although of course many cases of their being mixed together were on record. Into the other avenues of discussion he would forbear to enter.

Prof. Hughes, in reply, said that he wished the subject had been divided, so that they might have considered separately the different parts of the evidence and the different sources of error which had still to be eliminated. For instance, be thought it wouk be very well if they could have an exhibition of, and discussion on, the various ways in which nature breaks, cuts, and otherwise marks bone and stone as well as of various ruder forms known to be the result of human agency, so as to get clearer jdeas as to what might really be taken as evidence of design. He pointed out that the measure of the antiquity of the deposits containing the remains of man depended chiefly upon the time it wouid take to bring about certain geographical changes, either assuming that surrounding conditions had practically remained the same, or allowing for such differences as must have occurred, and of which we can estimate the effect. Applying this, while he agreed with Col. Lane Fox's remarks on the slow rate of waste of the Thames valley, he felt that we must make a very considerable allowance for the probability that during the period from the bronze age to our own man had interfered far more with the free course of the river than during all previous time. Nattre might also entirely change the rate of waste in such a case by a gentle upheaval or depression causing the more rapid or slower cutting back of the stream. With regard to the existence of depressions in non-calcareous strata he thought we could detect two ways in which they were formed. One by the forcing out of the plastic material all round the mass of gravel or clay thrown on it, and another when the gravel worked down into the puddled surface of a clay, the softer portions of which oozed up between the sinking stones. In all the cases which had come under his observation in which such phenomena occurred above palreolithic beds, the last appeared to be the explanation, as also in most cases where it was the only evidence for the more southeriy extension of glacial phenomena.

With regard to the Victoria Cave, be thought that the evidence was as yet decidedly argainst the pre-glacial age of any of the derosits containing even a suspicion of man. He believed that the deposits along the sides and in the side chambers of a limestone cave were frequently newer than those in the main cave, as the carbonated water, being thrown off the clay, must work the sides down. Whatever might be the age of the boulder clay on the floor at the mouth of the cave, he believed that the thin laver which occurred in the talus had iallen out of a pipe of which there were plenty in the limestone above, and that this clayey bank had ponded back the flood-waters and caused the accumulation of mud in the talus inside and the formation of the lami. nated clay.

Mr. Tiddeman ${ }^{1}$ had thought it unnecessary on this occasion to call aitention to geological minutiæ at the cave mouth, but as Prof. In ughes had raised the question of the age of the boulder clay there he was bound to follow him. Prof. Hughes said the boulder clay fell from the cliff at a time long subsequent to the date when the bones were deposited, but in drawing his section he had omitted a very important feature. They had to dig through twenty feet of talus before they came to the boulder clay, at the back of which was the hyæna bed; that represented a very considerable lapse of time since the boulders were deposited there. If the boulder clay fell at a subsequent period how was it that it was at the base of all the talus and not mixed up with it. If it fell before the talus began to form it might practically be considered of glacial age. As regards the reindeer in the lower bed, only one very doubtful specimen had been found since he had had charge of the excavations. The chief matter to be considered was whether this fauna which had been found in Europe and in England with human handiwork, occurred at a time which could ise correlated with certain great physical events. All the facts which he had noticed seemed to harmonise with the idea that there had been in England two well-marked glacial periods, and these both prior to the much lesser event of the upper boulder clay of Lancashire. For instance, the boulders made into implements which Prof, Hughes bad referred to in Pontnewydd Cave, need not have belonged to the latest glaciation of that country. Mr. Tiddeman would not dispute the fact of a fibula making its way down into the earth, especially after Prof. Rolleston's experience, but in the Victoria Cave it would have

I In the abstract of Mr. Tiddeman's paper, p. 7o, line 4o, non-gravcls sluould be riter-sravols; line 44 , ther post-glacial should be there postglacial. great difficulty. If it were soft mud it might have a chance of getting down, but if it were modern other modern things would go down with it unless it had a start. [Prof. Rolleston said it was pointed at both ends.] Mr. Tiddeman did not think there was a possibility of its working its way down. There were large blocks of stone and beds of stalagmite which had to be blasted in getting down to it. He hoped geologists would bear in mind as new facts cropped up, the suggestion that we had had two glacial periods.

\section{THE GREENWICH OBSERVATORY REPORT}

THE Report of the Astronomer-Royal at the annual visitation on Saturday contained nothing extraordinary with respect to the ordinary work of the Observatory. With reference to extraneous work, there are one or two points worthy of notice.

First, as regards the operations for the transit of Venus, the Astronomer-Royal reports as follows :-

The computing staff under Capt. Tupman has by degrees been reduced to two junior computers within the Observatory; and one or two computers external to the Observatory, who are employed on large groups of systematic calculations, for which they are remunerated by tariff. The principal part of the calculations remaining at the last report was that applying to the determination of the geographical longitudes of fundamental stations. At the moment of my writing, the last of these (the longitude of Observatory Bay, Kerguelen) is not absolutely finished; but I trust that it will be so before my presentation of this report; and then I shall be in position to offer the first determination of correction to parallax from eye-observations of the transit.

The method of determining the geographical longitude of the principal station in each group by vertical transits of the moon has been found very successful at Honolulu and Rodriguez. For stations in high south latitude, horizontal transits are preferable; for Kerguelen, as I have mentioned, the work is not quite completed. (It will be remembered that the longitude of Mokattam, the principal Egyptian station, was determined by telegraph.) The corrections to the moon's tabular places have been deter. mined with much care froin meriaional observations at the prin cipal European observatories.

The differences of longitude, or the relations of clock-times, within the groups of stations, are ascertained.

These calculations must be followed by the preparation of the factors of errors of various elements. Little progress is made in these; the work will not be heavy.

No further advance is made in the photographic reductions. The work is large, but it is simple, and will not be oppressive.

Second, as regards the numerical lunar theory :-

In the algebraical theory an alteration has been made, by the substitution of the equation of radial forces for the equation of vis viva. Nearly all the numbers had been computed, and the additional numerical operation was small.

The numerical calculations of the factors of symbolical variations are advancing; and the computations of the perturbing side of the equations, with due attention to the terms requiring extension of decimals, are in progress.

The numerical errors to which I alluded in the last report are corrected; and I do not think that any systematic error now remains.

With the view of preserving, against the ordinary chances of destruction or abandonment, a work which is already one of considerable magnitude, I have prepared and have printed as Appendix to the Greenwich Observations (with additional copies as for a separate work) the ordinary equations of lunar disturbance, the novel theory of symbolical variations, and the nurnerical developments of the quantities on the first side of the equations. The last of these will ultimately require some additions for the terms whose magnitude is increased (in algebraical development).

The work is perhaps somewhat larger than $I$ anticipated, and the regularity of its progress has been disturbed by very frequent interruptions of my owm attention, occasioned chielly by annoying occupations on the transit of Venus. I trust that it will in future go on in a more orderly and more rapid way.

Sir George Airy concludes his report with the following general remarks :-

The subject which, I think, must first present itself to the mind of anyone who has traced the history of the observatory is the increase in the number and the fulness of our occupations. 
Of these one in particular (altazimuth-observations of the moon) has originated with myself; others, from the suggestions of the Board of Visitors, or from the obvious demands of the scientific world.

This increase is felt even in our buildings and grounds ; every corner of every room is or will shortly be occupied; and the form of the ground almost forbids extension.

The printing of the steps of the reductions of observations (which originated with myself more than forty years ago) naturally increased the labour within the observatory, as well as the expenses without it. This printing, however, must never be abandoned. But there is another part, of which the policy still appcars to me somewbat doubtful, namely, the printing in extenso of every figure of original observations, it being remarked that the originals or extracts are always open to astronomers. I brought the question of suppressing these before the Board of Visitors many years ago; but the opinions of astronomers (I cite in particular the honoured name of $\mathrm{M}$. Biot and that of $\mathrm{Mr}$. Johnson) were so strongly adverse to it, that $I$ laid aside all further thoughts of it; and I do not even now profess to entertain a decided opinion.

The three points, however, to which. I have alluded (the extent of scientific occupations, the enlargement of buildings, and the amount of printing) must before long engage the atten. tion of the Visitors.

\section{RECENT RESEARCHES AMONG THE LOWER SARCODE ORGANISMS}

THE customary annual address on the occasion of the anniversary of the Linnean Society was, on Wednesday, the 24th May, delivered by the President, Prof. Allman, F.R.S. In continuation of his last year's summary of the progress in this department of biology, he dwelt upon the important additions to our knowledge of these organisms, due to the investigations of Archer in our own country and of Hertwig and Lesser, Franz Filhard Schulze, and Greeff in Germany.

The discovery of many new monothalamic Rhizopods of fresh water and the important additions made by the British and German investigators to our knowledge of their protoplasmic bodies were brought in review before the meeting. These monothalamic forms may be divided in accordance with the nature of their pseudopodia ; in some these processes being short, thick, and finger-shaped (Lobosa); in others long, slim, and filiform (Fitifcra). The former were illustrated by Hyalosphenia, with its smooth, transparent shell, and by Quadruta, with beautifully sculptured shell; and the latter by Gromia, with its very long filiform reticulated pseudopodia; and by Microsromia socialis, vitich has the curious babit of forming colonies by the association of numerous individuals, which become united to one another by the mutual fusion of their pseudopodia. The remarkable form of reproduction discovered by Hertwig in Microgromia was also descrited. Hertwig had shown that in this Rhizopod the protoplasm divides by spontaneous fission into two segments, one of which remains in the shell, while the other forces its way out, assumes an oval shape, develops, instead of pseudopodia, two vibratile flagella, and becomes a free-swimming flagellate Zoospore, capable of ultimate development into the form of the adult. The very interesting discovery by Haeckel, that the contents of the so-called "yellow cells" of the Radiolaria become of a deep violet colour under the action of iodine, and are therefore mainly composed of starch, was also referred to among recent additions to our knowledge of the lower organisms. An account was then given of the remarkable and very significant researches of Messrs. Dallinger and Drysdale among the socalled "Monads,"-microscopic organisms which become developed in putrifying solutions of organic matter, and which, in their ordinary and apparently adult state swim about by the aid of vibratile flagella. These laborious and trustworthy investigators have shown that the flagellate monads may acquire an amceboid condition and move about by the aid of pseudopodia; that two such amceboid forms when they come in contact with one another become instantly blended together at the point of contact, that this blending becomes more and more intimate until the two individuals become completely fused together, when their mingled protoplasm assumes the form of a spherical sac filled with particles of immeasurable minuteness. These particles are germs destined for the reproduction of the individual. Their form can be demonstrated only by the highest powers of the microscope ; and by following them by means of a one-fifticth of an inch object glass, Messrs. Dallinger and Drysdale were enabled to trace their gradual development into the form of the adult. They further proved the remarkable and unexpected faci that these minute germs may be subjected to a teraperature of from $258^{\circ} \mathrm{F}$. to $300^{\circ} \mathrm{F}$. without losing their vitality and power of development, a fact of vast significance in its bearing on experiments connected with the question of spontaneous generation. Finally attention was drawn to the quite recent discovery of IHertwig and F. E. schnize of a nucleus in the Foraminifera. By this discovery the true systematic position can now be assigned to the Foraminifera, which must accordin region of Cytodes or non-nucleated protoplasm masses (to which they had been hitherto relegated), and placed on a much higher stage in the great division of the Rhizopoda. Resting on these facts F. E. Schulze has attempted to represent by the aid of a genealogical tree the mutual affinities and derivation from one another of the various members of the Rhizopoda. The base of the tree where its stem is as yet tundivided, consists of the primitive forms--mere non-nucleated Cytodes represented by Haeckel's Monera (Protogenes, Protamaba, \&c.). From these by the differentiation of a nucleus in their protoplasm are evolved the nucleated forms (Amcba, fresh-water Monothalamia, Foraminifera, Heliozoa, \&c.) which constitute the sub-divisions into which the stem branches off. These repeat the various modifications of psendopodia (Lobose, Filiform, \&c.) which had already existed in the primitive forms, and which they thus derive by inheritance from their non-nucleated progenitors. Finally through the branch of the Heliozoa we are conducted to the ultimate twigs former by the families of the Radiolaria, in which we find not only nuclei but a "central capsule" indicating the highest grade of differentiation attained by any member of the group.

\section{THE NORWEGIAN DEEP-SEA EXPEDITION}

THE Norwegian Deep-Sea Expedition will have started from Bergen on its second summer cruise in the steamer Boringen. It has been decided by the proper authorities that the expedition, like last year's, shall be commanded by Capt. Wille with Lieut. Petersen as first officer. The scientific staff of the expedition is also the same as the previous year with the exception of the chemist, whose post is this year filled by Herr H. Torno.

The following is the approved plan of the expedition of the present year.

The equipment of the vessel and the determination of its magnetic constants were to be completed by June I. In studying the temperature in the deep sea over the banks off the West Coast, it has become evident that accurate observations are wanting in the Norwegian Rende. In order to obtain these the vessel will go from Bergen direct to sea, and following the bottom of the Rende, take accurate observations there. Farther to the north several of last year's observations may also be verified.

The first proper field of work is the Norwegian coast banks to the north of Ramdalen. From existing observations it is probable that the "Havbro," where the bank sinks toward the depths of the Polar Sea, and where the ice-cold water begins at the bottom, lies at least twenty-five geographical miles from the coast. Between Rœst and the point off Ramdalen, where the expedition last year found a depth of about sixty fathoms with a rocky bottom ten miles from land, it is considered probable that there runs a more or less continuous ridge of rock.

The position and characteristics of the "Havbro" and the supposed ridge form main points in the examination of the banks. This goes on by forming cross-sections perpendicular to the coast. The sections, like last year's, are to be at a distance of twelve or thirteen geographical miles asunder. Their inner boundary is to be the outermost line of the special hydrographical survey. Their outer boundary is where the temperature at the bottom of the sea is $\div 1^{\circ} \mathrm{C}$, , or thereby. In each"section besides the observation of the temperature at each sounding, at "least three other series of observations are required, one at the inner boundary, one at the "Havbro," at its inner edge, and one at the outer limit of the section. The number of soundings will depent on the bottom being found more or less even as the work goes on.

In order to leave as much time as possible for work in the depths of the Polar Sea, and at Jan Mayen and the Greenland ice, there will be carried on, along with the survey of the banks, the examination of the Umbellularia region to a depth of $\mathbf{I}, 000$ fathoms in every third cress-section. If circumstances permit 